\title{
A Study of the Relationship between Electricity Consumption and GDP Growth in Hainan International Tourism Island of China
}

\author{
Xiaohua Hu (Corresponding author) \& Xiao Lin \\ School of Mathematics and Statistics, Hainan Normal University, Haikou 571158, China
}

Tel: 86-577-6590-9057_E-mail: 1241957415@qq.com

Received: December 17, 2012

Accepted: January 12, $2013 \quad$ Online Published: March 7, 2013

doi:10.5430/rwe.v4n1p109

URL: http://dx.doi.org/10.5430/rwe.v4n1p109

\begin{abstract}
By making use of the stationary test, co-integration test, Granger Causality and Error Correction Model(ECM), we research the relationship between the electric power consumption of the whole society and GDP growth in Hainan Island from 1988 to 2009. In particular, we study the relationship between that of three major industries and the GDP growth, namely, the primary industry, the secondary industry and the tertiary industry and the GDP growth in Hainan Island from 1990 to 2009. Moreover with the assistance of Eviews 6.0 and Spss 17.0, we respectively establish the long-term equilibrium models and ECMs for them, further explain the established models, obtain some interesting results.
\end{abstract}

Keywords: Co-integration test, Granger causality, Error Correction Model (ECM), GDP

\section{Introducation}

Hainan Island is the smallest province of China. It was made a separate province in 1988. It was also known as the largest Special Economic Zone. It's special geographical location and unique climatic conditions makes its economical development model different from that of the another provinces in China. The three major industries' contribution on the GDP growth of Hainan Island is as follows. (1) The tertiary industry is dominant, (2) The primary industry is second to it, and (3) the secondary industry is last. The primary industry, the secondary industry, the tertiary industry of Hainan provincial economy make $35.6 \%, 23.3 \%, 41.1 \%$, respectively. In contrast to that, the ratio of three major industries in China is $15.2 \%, 51.2 \%, 33.6 \%$, respectively and the world is $6.5 \%, 31.6 \%, 61.9 \%$, respectively.

Since the electrical power consumption plays an important role in the economic development, so the relationship between the electrical power consumption and the economic growth has now been well researched in a lot of literatures. These research objects mainly are national level. For instance, in the recent papers, Qiang Hou (2009) studied the relationshipship between the energy consumption growths and the economic growth in China. Chun-Yu Ho, Kam Wing Siu (2007) analyzed a dynamic equilibrium of electricity consumption and the GDP growth in Hong Kong. Sheng-Tung Chen (2007) studied the relationship between the GDP growth and the electricity consumption in 10 Asian countries. Jaruwan Chontanawat (2006) reviewed and tabulated the mainly research on the relationship between the energy consumption and the economic growth from 1985 to 2005. Lee (2005) investigated the causality between energy consumption and the economic growth for 18 developing countries by using Panel Co-integration technique and ECM, finding energy-GDP causality exist from 1975 to 2001. Morimoto \& Hope (2004) analyzed the relationship between the electricity consumption and the GDP growth in Sri Lanka from 1960 to 1998 by using Granger Test. In all these papers, however, there is no any one associated with Hainan Island. Up to date, there are no papers to study the relationship between the GDP growth and the Electrical power consumption in Hainan Island. In this study, we not only take care of the relationship between the electrical power consumption and the GDP growth of Hainan Island from 1988 to 2010, particularly between that of three major industries and their GDP growth, and that of the primary industry, the tertiary industry and the GDP growth in Hainan Island, but also we further analyze these relationships in the long run, the interacting fluctuation in the short run. A similar (even more detailed) study would be beneficial in Hainan Island to design an economic policy framework for the GDP growth and the energy consumpation. 


\section{Methodology}

Our method mainly involves tests for the stationary of the variables, unit root, co-integration, Granger Causality and Error Correction Model (ECM). There are lots of papers available that introduce how to test the stationary of the variables using the Augmented Dickey-Fuller (ADF), how to test the causality from variable A (B) to variable B (A) using the Granger and how to test the co-integration between variables using the Johansen (or others) technique if co-integration is found. In this paper, here, we mainly introduce the $A D F$ and ECM approaches. Here let's take $Y_{t}$ as example, the ADF test is based on $\mathrm{H}_{0}: Y_{t}$ is not $\mathrm{I}(0)$ which is given by the following equation(2). If the calculated ADF statistics are less than their critical values from Fuller's table, then the null hypothesis $\left(\mathrm{H}_{0}\right)$ is rejected and the series are stationary or integrated or I(1). Assume that

$$
\begin{array}{cc}
\Delta Y_{t}=\alpha_{0}+\alpha_{1} t+\eta Y_{t-1}+\sum_{j=1}^{p} \lambda_{j} \Delta Y_{t-j}+\varepsilon_{t} \quad t=1,2, \cdots, T \\
Y_{t}=\alpha_{0}+\alpha_{1} t+\rho Y_{t-1}+\sum_{j=1}^{p} \lambda_{j} \Delta Y_{t-j}+\varepsilon_{t} \quad t=1,2, \cdots, T
\end{array}
$$

Where $\Delta$ is the difference operator, and $\alpha_{0}, \alpha_{1}, \eta, \lambda_{j}$ are parameters to be estimated, $\varepsilon_{t}$ is a white noise, $p$ is selected.

Suppose that there be the long-run equilibrium relationship among variable $Y_{t}, X_{t}$ and $Z_{t}$ below

$$
Y_{t}=\alpha_{0}+\alpha_{1} X_{t}+\alpha_{2} Z_{t}+u_{t}
$$

However, actually variable $Y_{t}, X_{t}$ and $Z_{t}$ seldom exist the long-run equilibrium relationship at $t$ moment. Let variable ecm $e_{t}=\mu_{t}=Y_{t}-\alpha_{0}-\alpha_{1} X_{t}-\alpha_{2} Z_{t}$, which establish multiple variables two-order error correction model (ECM) below.

$$
\Delta Y_{t}=\lambda e c m_{t-1}+\beta_{1} \Delta X_{t}+\beta_{2} \Delta X_{t-1}+\gamma_{1} \Delta Z_{t}+\gamma_{2} \Delta Z_{t-1}+\varepsilon_{t}
$$

Where $\varepsilon_{t}$ is a white-noise series and $\alpha_{0}, \alpha_{1}, \alpha_{2}, \lambda, \beta_{1}, \beta_{2}, \gamma_{1}, \gamma_{2}$ are parameters to be estimated.

\section{Empirical Analysis and Modelling}

\subsection{The Relationship between the Electric Power Consumption of the Whole Society and the GDP Growth}

We can gather data from Hainan statistics yearbook (see table 1). Let $Q_{t}$ denotes the electric power consumption of the whole society in Hainan Island, $G D P_{t}$ does GDP the growth from 1988 to 2010, where $t=1,2, \ldots, 23$. Taking natural logarithm for $Q_{t}$ and the $G D P_{t}, \ln Q_{t}, \ln G D P_{t}$. Testing for the stationary of the variables $\ln Q_{t}$ and $\ln G D P_{t}$ can be done by making use of ADF and PP (see table 2). Granger Causality test for $\ln Q_{t}$ and $\ln G D P_{t}$ (see table 3). We establish the co-integration relationship and ECMs below

$$
\ln Q_{t}=1.15 \ln G D P_{t}-2.868
$$




$$
\ln G D P_{t}=0.87 \ln Q_{t}+2.485
$$

$$
\begin{aligned}
\Delta \ln Q_{t}= & 0.024+0.444 \Delta \ln G D P_{t-1}+0.232 \Delta \ln Q_{t-1} \\
& -0.023(\ln Q-1.15 \ln G D P+2.87)_{t-1}+\hat{\varepsilon}_{t}
\end{aligned}
$$

$$
\begin{aligned}
\Delta \ln G D P_{t} & =0.07+0.562 \Delta \ln G D P_{t-1}-0.146 \Delta \ln Q_{t-1} \\
& -0.514(\ln G D P-0.87 \ln Q-2.49)_{t-1}+\hat{\varepsilon}_{t}
\end{aligned}
$$

\subsection{The Relationship between the Electric Power Consumption of Three Major Industries and the GDP Growth}

We regard the electric power consumption of the primary industry, the secondary industry, the tertiary industry are $Q_{1 t}, Q_{2 t}, Q_{3 t}$ respectively, they are denoted by $Q_{i t}, i=1,2,3$, while the corresponding GDP growth are denoted by $G D P_{i t}, i=1,2,3$. The time range of sample data is from 1990 to 2009 . ie. $t=1,2, \ldots, 20$. (See table 4 ). From the ADF and Granger Causality test for $\ln Q_{i t}$ and $\ln G D P_{i t}$ respectively in Table 5, table 6. Hence, we establish the co-integration relationship and ECMs below

$$
\begin{aligned}
& \ln G D P_{1 t}=0.024518 \ln Q_{1 t}+8.858897 \\
& \ln Q_{3 t}=-2.439+1.002 \ln G D P_{3 t}
\end{aligned}
$$

$$
\begin{aligned}
\Delta \ln G D P_{1 t}= & -0.035+1.381 \Delta \ln G D P_{1 t-1}+0.008 \Delta \ln Q_{1 t}+0.013 \Delta \ln Q_{1 t-1} \\
& -1.351(\ln G D P-0.700151 \ln Q 4.121628)_{1 t-1}+\varepsilon_{1 t} \\
\Delta \ln Q_{3 t}= & 0.072+0.235 \Delta \ln Q_{3 t-1}+0.288 \Delta \ln G D P_{3 t}-0.184 \Delta \ln G D P_{3 t-1} \\
& -0.673(\ln Q-1.002 \ln G D P+2.439)_{3 t-1}+\varepsilon_{3 t}
\end{aligned}
$$

3.3 The Relationship between the Electric Power Consumption of the Primary Industry, the Tertiary Industry and Their Corresponding GDP Growth

From the previous section, we realize that there exist co-integration relationship among the primary's electric power consumption, the tertiary industry's and the GDP growth from 1990 to 2009, via relevant analysis and test. Now we are able to establish the co-integration relationship and ECMs as below

$$
\begin{gathered}
\ln G D P_{t}=4.6590+0.3915 \ln Q_{1 t}+0.3668 \ln Q_{3 t}+\hat{u}_{t} \\
\hat{u}_{t}=0.6655 \hat{u}_{t-1}+\hat{\varepsilon}_{t} \\
\Delta \ln G D P_{t}=0.064+0.206 \Delta \ln Q_{1 t}+0.232 \Delta \ln Q_{3 t} \\
-0.121\left(\ln G D P-4.6590-0.3915 \ln Q_{1}-0.3668 \ln Q_{3}\right)_{t-1}+\hat{\varepsilon}_{t}
\end{gathered}
$$




\section{Observations}

4.1 In the Long Run, How the Change of $Q_{t}$ Affects the GDP Each Other

By (5), (6), $Q_{t}\left(G D P_{t}\right)$ will change $1.15 \%(0.87 \%)$ when $G D P_{t}\left(Q_{t}\right)$ changes $1 \%$; In details, by (9), (10), $G D P_{1 t}$ will change $0.024518 \%$ when $Q_{1 t}$ changes $1 \%, Q_{3 t}$ will change $1.002 \%$ when $G D D_{3 t}$ changes $1 \%$; by (13), GDP $P_{1 t}$ will change $0.3915 \%$ when $Q_{1 t}$ changes $1 \%$ and $Q_{3 t}$ keeps unchange, or $G D P_{1 t}$ will change $0.3668 \%$ when $Q_{3 t}$ changes $1 \%$ and $Q_{1 t}$ keeps unchange. because of the discussed coefficients are positive, thses changes are the same dirction, or, increase or reduce at the same time.

\subsection{In the Short Run, How the Fluctuation of $Q_{t}$ Affects $G D P_{t}$}

By (7), (8), the fluctuation of $Q_{t}\left(G D P_{t}\right)$ can be composed of two parts, the first part is the effect of $Q_{t}\left(G D P_{t}\right)$ deviating from long-run equilibrium, the coefficient size of $\mathrm{ecm}_{t-1}$ reflects adjusting strength of deviating from long-run equilibrium, the coefficient stimation value $-0.023(-0.514)$ shows that when the short-run fluctuation deviates from the long-run equilibrium, $Q_{t}\left(G D P_{t}\right)$ will be pulled back to equilibrium state by adjusting strength $0.023(0.514)$. it is obvious to see the adjusting strength of $G D P_{t}$ is more bigger than that of $Q_{t}$; the second part is the total effect of the two short-run fluctuation terms, in(7),(8), they include lag-one fluctuation terms $\Delta \ln G D P_{t-1}$ and $\Delta \ln Q_{t-1}$, coefficients $0.444,0.232,0.562,-0.146$ respectively reflect the effect strength size of short-run fluctuation. In (8), it is obvious to see that the lag-one fluctuation of $\ln Q_{t}$, or $\Delta \ln Q_{t-1}$ affects the fluctuation of $G D P_{t}$, coefficient -0.146 shows the effect is the reverse. by (11), the fluctuation of $G D P_{1 t}$ can be composed of two parts, the first part is the effect of $G D P_{1 t}$ deviating from long-run equilibrium, the coefficient -1.351 reflects adjusting strength of deviating from long-run equilibrium, it shows that when the short-run fluctuation deviates from the long-run equilibrium, $G D P_{1 t}$ will be pulled back to equilibrium state by adjusting strength 1.351 . The second part is the total effect of the three short-run fluctuation terms, they include lag-one fluctuation terms $\Delta \ln G D P_{1 t-1}$, $\Delta \ln Q_{1 t-1}$ and the current fluctuation term $\Delta \ln Q_{1 t}$, coefficients $1.381,0.008,0.013$ respectively reflect the effect strength size of short-run fluctuation. In the same way, we can similarly analyse (12) and (14).

\subsection{Macroscopic and Microscopic Fluctuation Structure of $G D P_{t}$}

If we can say that (6) reveals the relationship between the electric power consumption of the whole society and GDP growth in Hainan Island, then (13) certainly reveals more detailed construction. The electric power consumption in the first industry and the tertiary industry influences the GDP growth in Hainan Island. If we are allowed to say that (8) reveals the macroscopic fluctuation structure of $G D P_{t}$, then (14) must have revealed the microscopic fluctuation structure.

\section{Conclusion}

It is the economic growth (electric power consumption) that granger causes the electric power consumption (economic growth) (1988-2009). The electric power consumption in the primary industry granger causes the economic growth in its industry, the tertiary industry' GDP granger causes its electric power consumption (1990-2009). The electric power consumption of the primary industry and the tertiary industry granger cause the economic growth. The secondary industry's GDP and the electric power consumption aren't in the same order integration, there doesn't exist co-integration relationship between them. It isn't clear that the electric power consumption in the secondary industry influences the GDP growth in Hainan Island (in fact, the secondary industry in Hainan Island is very weak). We are sure that by enhancing the energy using efficiency, and strengthening the development of the primary industry and the tertiary industry, in particular, the trengthening the development of the tertiary industry, in the near future, most likely make Hainan Island a true international tourism island. 


\section{References}

Altinay, G., \& Karagol, E. (2005). Electricity Consumption and Economic Growth: Evidence from Turkey. Energy Economics, 27, 849-856. http://dx.doi.org/10.1016/j.eneco.2005.07.002

Banerjee, A., Dolado, J.J., Galbraith, W., \& Hendry, D.F. (1993). Cointegration, Error Correction and the Econometric Analysis of Nonstationary Data. Oxford University Press, Oxford. http://dx.doi.org/10.1093/0198288107.001.0001

Ghali, El-Sakka. (2004). Energy Use and Output Growth in Canada: A Multivariate Co-integration Analysis. Energy Economics, 26, 225-238. http://dx.doi.org/10.1016/S0140-9883(03)00056-2

Huang, Xiuhai. (2012). Research on Dynamic Conduction Effect between Economy and IPO Fund Based on Cointegration and Non- symmetric ECM. Research on Economics and Management, 2, 57-62.

Jumbe, C. B. L. (2004). Co-integration and Causality between Electricity Consumption and GDP: Empirical Evidence from Malawi. Energy Economics, 26, 61-68. http://dx.doi.org/10.1016/S0140-9883(03)00058-6

Lee, C. (2005). Energy Consumption and GDP in Developing Countries: A Co-integrated Panel Analysis. Energy Economics, 27, 415-427. http://dx.doi.org/10.1016/j.eneco.2005.03.003

Qiang, Hou. (2009). The Relationshipship between Energy Consumption Growths and Economic Growth in China. International Journal of Economics and Finance, 1(2), 232-237.

Wolde, Rufael. (2005). Energy Demand and Economic Growth: The African Experience. Journal of Policy Modeling, 27, 891-903. http://dx.doi.org/10.1016/j.jpolmod.2005.06.003

Yang, H. Y. (2000). A Note of the Causal Relationshipship between Energy and GDP in Taiwan. Energy Economics, 22, 309-317. http://dx.doi.org/10.1016/S0140-9883(99)00044-4

Yoo, S. H. (2005). Electricity Consumption and Economic Growth: Evidence from Korea. Energy Policy, 33, 1627-1632. http://dx.doi.org/10.1016/j.enpol.2004.02.002

Table 1. The whole society electricity consumption and GDP

\begin{tabular}{ccc}
\hline year & $\begin{array}{c}\text { The whole society electricity } \\
\text { consumption (KWH) }\end{array}$ & GDP(100 million yuan $)$ \\
\hline 1988 & 8.7 & 77 \\
1989 & 12.41 & 91.32 \\
1990 & 13.96 & 102.42 \\
1991 & 16.46 & 120.52 \\
1992 & 19.79 & 184.92 \\
1993 & 24.69 & 260.41 \\
1994 & 28.99 & 331.98 \\
1995 & 31.53 & 363.25 \\
1996 & 32.81 & 389.68 \\
1997 & 34.6 & 411.16 \\
1998 & 36.69 & 442.13 \\
1999 & 38.65 & 476.67 \\
2000 & 42.23 & 526.82 \\
2001 & 44.86 & 579.17 \\
2002 & 51.31 & 642.73 \\
2003 & 59.75 & 713.96 \\
2004 & 68.66 & 819.66 \\
2005 & 81.61 & 918.75
\end{tabular}




\begin{tabular}{lcc}
2006 & 97.66 & 1065.67 \\
2007 & 113.25 & 1254.17 \\
2008 & 122.97 & 1503.06 \\
2009 & 133.77 & 1654.21 \\
2010 & 158.22 & 2064.5 \\
\hline
\end{tabular}

Table 2. ADF and PP test results for $\ln G D P_{t}, \ln Q_{t}$

\begin{tabular}{cccc}
\hline Variables & Test form $(\mathrm{C}, \mathrm{T}, \mathrm{K})$ & ADF & PP \\
\hline $\ln G D P_{t}$ & $(\mathrm{C}, \mathrm{T}, 1)$ & $-3.471413^{*}$ & -1.825850 \\
$\Delta \ln G D P_{t}$ & $(\mathrm{C}, \mathrm{N}, 0)$ & $-2.992384^{*}$ & $-2.682862^{*}$ \\
$\ln Q_{t}$ & $(\mathrm{C}, \mathrm{T}, 4)$ & $-4.026510^{* *}$ & -2.819583 \\
$\Delta \ln Q_{t}$ & $(\mathrm{C}, \mathrm{N}, 1)$ & -1.476793 & $-4.159875^{* * *}$
\end{tabular}

$\mathrm{C}, \mathrm{T}$ and $\mathrm{K}$ denote respectively constant term, time trend term and number of lag-order in tested equation, $\mathrm{N}$ denotes there isn't constant term or time trend term in tested equation. ${ }^{* * *}, * *$ and $*$ denote the significance level $1 \%, 5 \%$ and $10 \%$, respectively

Table 3. Test of Granger for $\ln G D P_{t}$ and $\ln Q_{t}$

\begin{tabular}{cccc}
\hline Null Hypothesis & Optimal lag-order & F-Statistic & Prob. \\
\hline $\ln G D P_{t}$ does not Granger Cause $\ln Q_{t}$ & 2 & 4.09319 & $0.0381^{* *}$ \\
$\ln Q_{t}$ does not Granger Cause $\ln G D P_{t}$ & 2 & 3.04356 & $0.0777^{*}$ \\
\hline
\end{tabular}

** and $*$ denote the significance level $5 \%, 10 \%$, respectively.

Table 4. Three major industries' electricity consumption and GDP

\begin{tabular}{lcccccc}
\hline & \multicolumn{2}{c}{ Primary industry } & \multicolumn{2}{c}{ Second industry } & \multicolumn{2}{c}{ Third industry } \\
\cline { 2 - 7 } & $\begin{array}{c}\text { Electricity } \\
\text { consumption } \\
\text { year }\end{array}$ & $\begin{array}{c}\text { GDP(100 } \\
\text { million }\end{array}$ & $\begin{array}{c}\text { Electricity } \\
\text { consumption } \\
\text { (KWH) }\end{array}$ & $\begin{array}{c}\text { GDP(100 } \\
\text { million }\end{array}$ & $\begin{array}{c}\text { Electricity } \\
\text { consumption } \\
\text { (KWH) }\end{array}$ & $\begin{array}{c}\text { GDP(100 } \\
\text { million }\end{array}$ \\
1990 & 1.41 & 45.71 & 8.85 & 20.19 & 3.17 & 36.52 \\
1991 & 0.89 & 49.8 & 10.29 & 24.71 & 4.4 & 46.01 \\
1992 & 1.07 & 53.59 & 12.37 & 38.27 & 5.29 & 93.06 \\
1993 & 1.35 & 76.82 & 15.1 & 66.08 & 6.67 & 117.5 \\
1994 & 1.59 & 106.12 & 17.97 & 83.32 & 7.86 & 142.54 \\
1995 & 1.31 & 128.9 & 16.66 & 78.48 & 11.42 & 155.87 \\
1996 & 1.32 & 141.15 & 17.15 & 81.52 & 10.79 & 167.01 \\
1997 & 1.21 & 148.52 & 17.64 & 83.13 & 10.56 & 179.51 \\
1998 & 1.3 & 156.05 & 18.08 & 91.41 & 11.93 & 194.66 \\
1999 & 1.34 & 172.62 & 20.02 & 96.02 & 11.67 & 208.04 \\
2000 & 1.49 & 192 & 16.7 & 103.97 & 12.96 & 230.85 \\
2001 & 2.12 & 196.78 & 17.32 & 133.84 & 13.13 & 248.56 \\
2002 & 2.86 & 222.89 & 22.71 & 148.88 & 13.09 & 270.96 \\
2003 & 3.6 & 244.29 & 28.1 & 175.82 & 13.05 & 293.85
\end{tabular}




\begin{tabular}{ccccccc}
2004 & 3.7 & 278.76 & 35.04 & 205.6 & 17.18 & 335.3 \\
2005 & 4.62 & 300.75 & 44.73 & 240.83 & 20.43 & 377.17 \\
2006 & 5.37 & 323.48 & 55.91 & 308.62 & 23.7 & 433.57 \\
2007 & 5.94 & 361.07 & 66.53 & 364.26 & 26.6 & 528.84 \\
2008 & 5.79 & 436.04 & 70.34 & 423.55 & 30.21 & 643.47 \\
2009 & 6.33 & 462.19 & 73.92 & 443.43 & 34.21 & 748.59 \\
2010 & 7.92 & 539.83 & 87.19 & 571 & 39.6 & 953.67 \\
\hline
\end{tabular}

Table 5. ADF and PP test results for $\ln G D P_{i t}, \ln Q_{i t}(\mathrm{i}=1,2,3)$

\begin{tabular}{ccll}
\hline Variables & Test form $(\mathrm{C}, \mathrm{T}, \mathrm{K})$ & \multicolumn{1}{c}{ ADF } & \multicolumn{1}{c}{ PP } \\
\hline $\ln G D P_{1 t}$ & $(\mathrm{C}, \mathrm{T}, 0)$ & -0.998939 & -1.087549 \\
$\Delta \ln G D P_{1 t}$ & $(\mathrm{C}, \mathrm{N}, 0)$ & -2.626560 & $-2.690788^{*}$ \\
$\ln Q_{1 t}$ & $(\mathrm{C}, \mathrm{T}, 4)$ & $-3.738900^{*}$ & -2.621708 \\
$\Delta \ln Q_{1 t}$ & $(\mathrm{C}, \mathrm{N}, 0)$ & $-4.989768^{* * *}$ & $-4.708442^{* * *}$ \\
$\ln G D P_{2 t}$ & $(\mathrm{C}, \mathrm{T}, 0)$ & -2.039975 & -2.191740 \\
$\Delta \ln G D P_{2 t}$ & $(\mathrm{C}, \mathrm{N}, 0)$ & $-3.509670^{* *}$ & -2.018085 \\
$\ln Q_{2 t}$ & $(\mathrm{C}, \mathrm{T}, 0)$ & -0.973483 & -1.352655 \\
$\Delta \ln Q_{2 t}$ & $(\mathrm{C}, \mathrm{N}, 0)$ & -2.485213 & -2.510184 \\
$\ln G D P_{3 t}$ & $(\mathrm{C}, \mathrm{T}, 0)$ & $-3.322123^{*}$ & $-3.322123^{*}$ \\
$\Delta \ln G D P_{3 t}$ & $(\mathrm{C}, \mathrm{N}, 1)$ & $-11.85491^{* * *}$ & $-3.071644^{* *}$ \\
$\ln Q_{3 t}$ & $(\mathrm{C}, \mathrm{T}, 0)$ & -2.633654 & -2.624929 \\
$\Delta \ln Q_{3 t}$ & $(\mathrm{C}, \mathrm{N}, 1)$ & $-3.684755^{* *}$ & $-3.684755^{* *}$ \\
\hline
\end{tabular}

$* * *, * *$ and $*$ denote the significance level $1 \%, 5 \%$ and $10 \%$, respectively

Table 6. Test of Granger for $\ln G D P_{i t}$ and $\ln Q_{i t}(i=1,3)$

\begin{tabular}{lccl}
\hline \multicolumn{1}{c}{ Null Hypothesis } & lag-order & F-Statistic & \multicolumn{1}{c}{ Prob. } \\
\hline $\ln G D P_{1 t}$ does not Granger Cause $\ln Q_{1 t}$ & 5 & 2.37206 & 0.2115 \\
$\ln Q_{1 t}$ does not Granger Cause $\ln G D P_{1 t}$ & 5 & 14.2820 & $0.0117^{* *}$ \\
$\ln G D P_{3 t}$ does not Granger Cause $\ln Q_{3 t}$ & 4 & 3.80089 & $0.0598^{*}$ \\
$\ln Q_{3 t}$ does not Granger Cause $\ln G D P_{3 t}$ & 4 & 0.90128 & 0.5116 \\
\hline
\end{tabular}

$* * *, * *$ and $*$ denote the significance level $1 \%, 5 \%$ and $10 \%$, respectively 